\title{
TOMASZ SIKORA
}

(Olsztyn)

\section{KONCEPCJA MITÓW POLITYCZNYCH W FILOZOFII ERNSTA CASSIRERA I JEJ AKTUALNOŚĆ}

Rekonstrukcję Cassirerowskiej koncepcji mitów politycznych można przeprowadzić na przynajmniej dwa sposoby. Pierwszy niejako „wycinałby” z całości poglądów filozofia te szczególne obszary, które odnoszą się do interesującego nas zagadnienia i poddawał je analizie, nierzadko w oderwaniu od obszarów z założenia mniej istotnych. Łatwo byłoby wtedy uznać, że w związku z napiętą sytuacją w świecie lat 30. i 40. XX w. i bezpośrednim wpływem wydarzeń tamtego czasu na życie myśliciela żydowskiego pochodzenia, przesunął on punkt ciężkości swych zainteresowań z zagadnień teoriopoznawczych na filozofię polityki ${ }^{1}$. Taki sposób postępowania mógłby się właściwie ograniczyć do streszczenia ostatniego dzieła Cassirera, ukończonego tuż przed jego śmiercią 13 kwietnia 1945 r. Mitu państwa ${ }^{2}$, jedynej książce marburczyka w całości poświęconej problematyce mitów politycznych. Podobna metoda mogłaby co prawda jawić się jako atrakcyjna, choćby ze względu na swoją prostotę, lecz nie tylko nie oddałaby sprawiedliwości „duchowi” myśli autora Eseju o człowieku ${ }^{3}$, lecz byłaby z nim po prostu sprzeczna. Trudno dyskutować ze znaczeniem wpływu sytuacji politycznej na świecie, w którym przyszło żyć Cassirerowi na jego zainteresowanie przyczynami katastrof społecznych

\footnotetext{
1 Jak zauważa D. Ph. Verene, zagadnienia polityczne pojawiały się w pismach Cassirera jeszcze przed 1933 r., choć prawdą jest, że centralne miejsce zajęły w nich dopiero pod koniec życia filozofa (patrz: E. Cassirer, The Technique of Our Modern Political Myths, [w:] Symbol, Myth and Culture. Essays and Lectures of Ernst Cassirer 1935-1945, ed. by D. Ph. Verene, New Haven and London, 1979, przypis dolny, s. 242).

2 E. Cassirer, Mit państwa, przeł. A. Staniewska, Warszawa 2006 [dalej jako: Mit].

3 Tenże, Esej o czlowieku. Wstęp do filozofii kultury, przeł. A. Staniewska, Warszawa 1977 [dalej jako: Esej].
} 
i politycznych czy też problematyką ludzkiej racjonalności i irracjonalności. Jednak wydaje się, że nie tyle mamy tu do czynienia z całkowitym porzuceniem jednego obszaru zainteresowań na rzecz innego. Jest to raczej próba naświetlenia pewnego, szczególnie istotnego z punktu widzenia bieżących wydarzeń, fragmentu większej całości, obejmującej i zagadnienia teorii poznania, i filozofii polityki.

Metodyka wywodzącego się ze szkoły marburskiej Cassirera sprowadza się do czterech podstawowych założeń: prymatu pojęcia systemu nad pojęciem agregatu, prymatu pojęcia całości nad pojęciem części, prymatu pojęcia relacji nad pojęciem substancji i wreszcie prymatu pojęcia poznania (przedmiotu) nad pojęciem bytu (substancji) ${ }^{4}$. W takim ujęciu nie może być mowy ani o „wycinaniu” pewnych obszarów rzeczywistości celem poddania ich szczegółowej analizie, ani o ich prymacie wobec pozostałych, a zarówno epistemologia jak i filozofia polityki, podobnie jak np. nauki ścisłe, stanowią „prowincje” „regionu” nauk o kulturze, które rozumiane są jako teoretyczne zasady poznania wszelkich zobiektywizowanych wytworów ducha ludzkiego. Według wywodzącego się z marburskiej szkoły neokantyzmu Cassirera, matematyczno-przyrodniczy obszar obiektywizacji nie jest ani jedyny, ani szczególnie uprzywilejowany i to przeświadczenie stanowiło punkt wyjścia do budowy nowej teorii kultury ${ }^{5}$. Zgodnie z powyższym także koncepcję mitów politycznych Ernsta Cassirera należałoby rozpatrywać jako element większej całości, której poszczególne składniki są wzajemnie skorelowane i wyróżnione jako takie ze względu na swoją funkcję. Stanowiłoby to istotę drugiego sposobu rekonstruowania tej właśnie dziedziny zainteresowań marburczyka.

Mit polityczny w tym ujęciu należałoby uznać za „prowincję" filozofii mitu, stanowiącą z kolei „prowincję” filozofii kultury. Nie mówimy tu jednak o jakiejś konkretnej formie mitu, ani nie uznajemy go za właściwy ludom pierwotnym, naiwny sposób rozumowania. Dla Cassirera mit jest jedną z form świadomości, jedną z metod apriorycznego syntetyzowania różnorodności wrażeń, posługującą się właściwą sobie logiką ${ }^{6}$. Zadanie filozofii mitu polega właśnie na analizie owej

\footnotetext{
4 Przedstawienie problemu system-agregat z punktu widzenia myśli krytycznej znaleźć można w: I. Kant, Krytyka czystego rozumu, t. 2, przeł. R. Ingarden, Warszawa 1986, s. 386; w sprawie zagadnień całości i części oraz relacji i substancji patrz np.: E. Cassirer, Substancja i funkcja. Badania nad podstawowymi problemami krytyki poznania, Kęty 2008, s. 297-298; na ten temat także: P. Parszutowicz, The Idea of Transcendental Philosophy in Perspective of the Kantian Opposition of Aggregate and System, „Archiwum Historii Filozofii i Myśli Społecznej” 58, 2013; więcej na temat charakterystycznego dla neokantystów przyznawania pojęciu poznania prymatu nad pojęciem bytu np. w: W. Tatarkiewicz, Logika czystego poznania, [w:] tenże, Szkota marburska $i$ jej idealizm (W setna rocznice marburskiej dysertacji Profesora Wtadystawa Tatarkiewicza), red. P. Parszutowicz, Kęty 2010.

5 Szerzej na temat problemu możliwości innych obszarów obiektywizacji niż matematyczno-przyrodniczy w: E. Cassirer, Logika nauk o kulturze. Pięć studiów, przeł. P. Parszutowicz, Kęty 2011.

6 Por. Esej, s. 166-167.
} 
logiki myślenia mitycznego. Bazą dla takiego ujęcia problemu są pewne założenia epistemologiczne, zilustrowane w słowach Kanta: „Transcendentalnym nazywam wszelkie poznanie, które zajmuje się w ogóle nie tyle przedmiotami, ile naszym sposobem poznania przedmiotów, o ile sposób ten ma być a priori możliwy" 7 . Dla skupionych pod sztandarem filozofii transcendentalnej marburczyków najistotniejsza była bowiem analiza samej struktury poznania, a nie badanie empirycznych faktów poznania czy przebieg procesów poznawczych. Poznanie utożsamione tu z czystym myśleniem samo tworzy swój przedmiot i treść, ponieważ odwołanie się do świata zewnętrznego czy doświadczenia, naruszałoby pewność tegoż poznania. Jest ono w całości aprioryczne i oparte na funkcji syntezy, łączenia, dokonywanej według określonych zasad, których badaniem zajmuje się logika nauki. Według marburczyków, to właśnie syntetyzująca funkcja rozumu czyni naukę możliwą, będąc tym samym przedmiotem analizy poznania naukowego. Nie dysponując takimi syntezami mielibyśmy wyłącznie do czynienia ze zbiorem nieusystematyzowanych faktów, a więc analiza syntez poznawczych rozumu jest też analizą możliwości poznania teoretycznego w ogóle. W gruncie rzeczy zadawane przez szkołę Cohena i Natorpa pytanie o strukturę logiczną nauk przyrodniczych było kontynuacją Kantowskiego pytania o możliwość czystego przyrodoznawstwa ${ }^{8}$.

Cassirer przedefiniował problem aplikując transcendentalną metodę analizy apriorycznych syntez poznawczych do warunków możliwości wszelkich wytworów ducha ludzkiego. Skoro bowiem można pytać o możliwość czystego przyrodoznawstwa, można tė̇ zapytać o warunki możliwości nauk o kulturze ${ }^{9}$. Bez względu na to, jakich form nie przyjęłyby wspomniane wytwory ducha - nauka, sztuka, religia etc. - zawsze u ich podłoża leży jednocząca funkcja świadomości, która pozwala połączyć różnorodne wrażenia w uporządkowaną całość. Każda z tych form porządkowana jest według własnej „,wewnętrznej logiki”, ze względu na określoną funkcję, lecz ich punktem zbieżnym jest właśnie sam fakt syntezy. Akt porządkowania poprzedza (w sensie logicznym) wszelkie doświadczenie, a każde postrzeżenie jest już niejako „brzemienne” formą. Taka forma organizacji doświadczenia, określona strukturalna całość, nosi w systemie Cassirera nazwę form symbolicznych, z których każda we właściwy sobie sposób syntetyzuje dane empiryczne. „Brzemienność" lub też pregnancja, to z kolei nakierowanie funkcji symbolicznej

7 I. Kant, Krytyka czystego rozumu, t. I, wyd. cyt., s. 86.

8 Przedstawiona powyżej charakterystyka szkoły marburskiej jest siłą rzeczy nie tylko znacznie uproszczona, ale pomija także różnice dzielące jej poszczególnych przedstawicieli. Bardziej szczegółowe informacje w języku polskim znaleźć można np. w: A. Lisak, Filozofia transcendentalna między Heglem a Heideggerem. Od teorii poznania do ontologii, Gdańsk 2012; A. Noras, Kant a neokantyzm marburski $i$ badeński, Katowice 2000; tenże, Historia neokantyzmu, Katowice 2012 oraz: W. Hanuszkiewicz, Filozofia Hermanna Cohena w perspektywie sporu o jedność metody transcendentalnej, Warszawa 2011.

9 Zob. np.: E. Cassirer, Przedmiot nauki o kulturze, [w:] Logika. 
- podstawowej funkcji świadomości - na konkretny obszar sensu symbolicznego. To „prawdziwe 'a priori' (echtes 'Apriori') i to, co istotnie pierwsze (wesenmäßig Erstes). Właśnie na tym fenomenalnym poziomie biorą swój początek wszystkie formy symboliczne, zarówno modalne jak i jakościowe" 10.

Mit jest w interesującej nas koncepcji potraktowany właśnie jako jedna $\mathrm{z}$ form symbolicznych, czyli jedna z form syntetyzowania danych doświadczenia i jako taka pełni funkcję analogiczną do innych wyróżnionych przez Cassirera form nauki, sztuki, religii oraz języka. Żadna z nich nie może być uprzywilejowana, bo też żadna nie wyczerpuje tej specyficznej aktywności umysłu, która daje nam obraz świata jako całości zamiast chaosu wrażeń. Naturalnie rzecz biorąc jedność funkcji nie oznacza równej wartości poznawczej, bo na tym polu mit w oczywisty sposób ustępuje nauce.

Każda z form symbolicznych połączona jest więzią, którą Cassirer określa jako vinculum functionale, $\mathrm{w}$ opozycji do silnie akcentowanej $\mathrm{w}$ tradycji scholastycznej vinculum substantiale. Zadanie postulowanej przez niego „filozofii człowieka” ma przy tym polegać na odkrywaniu owej więzi funkcjonalnej łączącej mit, religię, naukę, sztukę i język, by ostatecznie dotrzeć do jej - wspólnych dla wyżej wymienionych - źródeł ${ }^{11}$.

Tak w wielkim skrócie przedstawiają się ogólne założenia teorii Cassirera, stanowiącej, jak to określiliśmy „region”, którego „prowincją” jest interesująca nas koncepcja mitów politycznych. Spróbujmy teraz wskazać najbardziej charakterystyczne cechy mitu czy też myślenia mitycznego, wychodząc od porównania tegoż z pozostałymi formami symbolicznymi. W opinii urodzonego we Wrocławiu filozofa na szczególną uwagę zasługuje związek mitu z językiem i sztuką. Jak pisze:

[...] sztuka, podobnie jak język, jest źródłowo całkowicie związana z mitem. Mit, język i sztuka początkowo stanowią określoną, niepodzielną całość, która stopniowo przemieniona zostaje w triadę niezależnych form twórczości duchowej. [...] ta sama mityczna właściwość ożywiania i hipostazowania, którymi obdarzone jest ludzkie słowo, pierwotnie przysługuje przedstawieniom, każdemu rodzajowi artystycznego wyrazu ${ }^{12}$.

Mit i język jako funkcje duchowe nie mogą być wywiedzione ze świata gotowych przedmiotów, ani uporządkowane wedle przysługujących im atrybutów, jako że one same czynią - każda na swój sposób - takie porządkowanie możliwym.

10 Więcej na temat pojęcia „symbolicznej pregnancji” i jego związków z psychologią postaci (Gestalt) w: P. Parszutowicz, Fenomenologia form symbolicznych. Podstawowe pojęcia i inspiracje „późnej” filozofii Ernsta Cassirera, Warszawa 2013, rozdz.: „Cassirerowskie pojęcie symbolicznej pregnancji i jego inspiracje".

11 Zob. Esej, s. 153.

12 Tenże, Language and Myth, trans. by S. Langer, New York 1953, s. 98. 
Logika typowa dla wiedzy teoretycznej opiera się bowiem na niższej (w ujęciu porządkowym) warstwie logiki języka. Wystarczy zauważyć, że każda próba zrozumienia jakichkolwiek zjawisk, tworzenia pojęć, musi być poprzedzona wysiłkiem ich nazwania. Z kolei mit ma charakter totalny, nie rozróżnia się tu przedmiotu i podmiotu, a brak odseparowania myśli od bytu skutkuje jednowymiarowym obrazem rzeczywistości. Logika właściwa językowi i myśleniu mitycznemu - w przeciwieństwie do logiki właściwej nauce - stosuje prawo ujednolicania, sprowadzania tego, co różnorodne, do jednej klasy, niwelując przy okazji wszelkie różnice i nierzadko zatracając wyjątkowy charakter przedmiotu (taka funkcja języka pozwala np. Indianom Cora zaliczać motyle do ptaków, jako że elementem wyróżniającym te ostatnie jest „latanie” 13). Tutaj każda część całości sama jest całością, a każdy okaz jest odpowiednikiem całego gatunku. "Część nie tylko reprezentuje całość, a egzemplarz swą klasę: one są tożsame z całością, do której należą" ${ }^{14}$. Tym samym docieramy do jednej z najbardziej typowych cech mitu - zasady pars pro toto (część zamiast całości), której bodaj najjaskrawsze przejawy odnajdziemy w magii. Chcąc przejąć władzę nad całością wystarczy uzyskać władzę nad jej dowolną częścią - np. włosem czy elementem ubioru danej osoby.

Tak jak w logice obowiązującej w nauce mamy do czynienia z rozszerzaniem obszarów percepcji i tworzenia pojęć, tak w przypadku mitu dochodzi do zgoła odmiennego procesu. Tutaj dochodzi do kompresji, „destylacji” danych do jednego określonego punktu. Właśnie poprzez taką „destylację” uzyskuje się istotę rzeczy, to, co ma „znaczenie”. Przy czym:

Całe światło skoncentrowane jest na jednym punkcie skupienia, którym jest 'znaczenie', podczas gdy wszystko, co znajduje się poza tymi punktami skupienia pojęć języka i mitu pozostaje praktycznie niewidoczne. Pozostaje 'nie-oznaczone' (un-remarked), ponieważ, i na tyle, o ile, nie jest wyposażone w żaden językowy czy mityczny 'znacznik' (marker) ${ }^{15}$.

W świecie, w którym nie ma podziału na myśl i byt i w którym każda część jest identyczna z całością nie ma też mowy o abstrakcji. Mit to wyłącznie teraźniejszość i konkret, to, co bezpośrednio, zmysłowo dane. Ponadto każda właściwość, która w języku legła u podstaw takiego czy innego zakwalifikowania danego zjawiska lub przedmiotu (tak jak to było w przypadku motyla i ptaków), w rzeczywistości mitycznej służyć może tworzeniu i rozpoznawaniu kolejnych obiektów wyróżnionych przez nadane im nazwy. Jeśli np. widok błyskawicy język charakteryzuje poprzez jej „wężowatość”, to automatycznie błyskawica staje się wężem.

\footnotetext{
13 Zob. tamże, s. 96.

14 Tamże, s. 92.

15 Tamże, s. 90-91.
} 
W ten sposób egipski bóg słońca przedstawiony jest z głową ptaka (sokoła), ponieważ w języku słońce funkcjonuje jako „latające po niebie” ${ }^{16}$. Nie znajdziemy w micie podziału na słowo i rzecz, znak i znaczenie - słowo tożsame jest z rzeczą, tak jak imię boga z nim samym.

Relacja tożsamości obejmuje cały dostępny człowiekowi świat, łącznie z przyrodą i życiem. Tu nie patrzy się na przyrodę ani pod kątem praktycznym, ani wyłącznie teoretycznym, dla człowieka pierwotnego jest ona sympatyczna.

Szczególny kierunek myśli lub szczególne ukierunkowanie wyobraźni ludzkiej nie jest najbardziej zasadniczą cechą mitu. Mit wyrasta z podłoża emocjonalnego i to podłoże nadaje wszystkim jego tworom swoje własne, specyficzne zabarwienie. Człowiekowi pierwotnemu bynajmniej nie brakuje umiejętności uchwycenia empirycznych różnic między rzeczami. Ale w jego koncepcji życia wszystkie te różnice zaciera uczucie silniejsze - głębokie przeświadczenie o zasadniczej i nie dającej się wymazać solidarności życia, która przerzuca pomost nad bogactwem i różnorodnością jego poszczególnych form ${ }^{17}$.

Przyroda jest „społecznością życia”, w której ludzie, rośliny i zwierzęta są na tym samym poziomie. Ta sama jedność dotyczy też życia pokoleń, tworzących nierozerwalny łańcuch, gdzie dusza dziadka odradza się w nowo narodzonym dziecku. Podział na przeszłość, przyszłość i teraźniejszość zostaje zatarty do tego stopnia, że mit rzuca nawet wyzwanie śmierci. Nie jest ona niczym naturalnym, odpowiedzialność za nią spada na zjawiska zewnętrzne, np. działanie magii. Dotykamy tu problemu kategorii, jakimi posługuje się logika mitu. Po raz kolejny okazuje się, że mit to nie przypadkowe i dowolne nagromadzenie danych doświadczenia, bowiem posługuje się takimi samymi apriorycznymi zasadami syntezy jak nauka. Także tu odnajdziemy kategorie przestrzeni, czasu, przyczynowości i ilości. „Mit i nauka - pisze Cassirer - różnią się nie jakością występujących kategorii, lecz ich modalnością. Rodzaje syntezy, jakie stosują w kształtowaniu jedności świata wrażeń, są analogiczne" 18 . Przeczy to także tezie o z gruntu irracjonalnym charakterze mitu. Człowiek pierwotny ucieka się do pomocy magii dopiero wtedy, gdy zawodzą go wszelkie inne znane i dostępne mu środki. To nie dokonywany w micie sposób interpretacji jest irracjonalny, ale przesłanki, z których wychodzi. Gdy właściwie je zrozumiemy i spojrzymy na nie oczami człowieka pierwotnego, mit przestanie się jawić jako nielogiczny. Ważnym jest także porzucenie prób czysto intelektualnej interpretacji mitu, ponieważ to nie myśl stanowi jego główną zasadę, ale uczucie.

\footnotetext{
16 Zob. tamże, s. 96-97.

17 Esej, s. 176.

18 E. Cassirer, Die Philosophie der symbolischen Formen, t. II, cyt. za: H. Buczyńska, Cassirer, Warszawa 1963, s. 94.
} 
Mit i religia pierwotna bynajmniej nie są całkowicie niezborne ani pozbawione sensu czy rozsądku. Ale ich wewnętrzna zgodność w znacznie większym stopniu zależy od jedności uczucia niż od reguł logicznych. [...] Jeśli nauka pragnie opisać i wyjaśnić rzeczywistość, musi uciec się do powszechnie stosowanej metody, jaką jest klasyfikacja i systematyzacja. [...] Ale umysł pierwotny ignoruje i odrzuca je wszystkie. Jego pogląd na życie jest syntetyczny, a nie analityczny ${ }^{19}$.

Życie niepodzielone na klasy i rodzaje stanowi ciągłość niepodlegającą żadnym rozróżnieniom, jednakże brak wyraźnych granic pomiędzy poszczególnymi dziedzinami życia oznacza także, że wszystko podlega prawu metamorfozy wszystko może zmienić się we wszystko. Nie istnieją także rzeczy obojętne, w świecie mitu nieustannie ścierają się ze sobą przeciwstawne siły nadając temu światu swoiście dramatyczny charakter. Każdy przedmiot jest dobry, albo zły, przychylny bądź nieprzychylny, pomocny lub złośliwy itd. Dotyczy to także czasu, przestrzeni czy liczby. Nie istnieje „czas w ogóle”, jest on ściśle związany z pewnymi wydarzeniami. W zależności od tego, jakie wiążą się z nim doświadczenia, uznaje się go bądź za czas „raju”, bądź „piekła”. Podobnie jest z przestrzenią: dla mitu nie ma miejsc obojętnych, każde jest mroczne i groźne, lub przyjazne i dobre, co oznacza, że zmiana miejsca jest zmianą jakościową. Jeśli natomiast wszystko podlega prawu metamorfozy, wszystko może też być przyczyną wszystkiego. Mityczne rozumienie przyczynowości oparte jest na zasadzie post hoc, ergo propter hoc (łac. po tym, więc wskutek tego). „Zwierzęta, które pojawiają się w pewnych porach, są powszechnie uważane za przynoszące dany sezon, za jego przyczynę; w myśleniu mitycznym jaskółka czyni wiosnę" 20.

Powołując się na prace współczesnych mu lingwistów, np. Antoine Meilleta, Cassirer dowodzi, że nie istnieje żaden „prelogiczny” język, który miałby być odpowiednikiem „prelogicznego" stanu umysłu ${ }^{21}$. Każdy, nawet najbardziej prymitywny język, posiada określoną strukturę logiczną. Podobnie jest z myśleniem. Jeśli mityczny sposób ujmowania rzeczywistości wydaje się nam paradoksalny czy po prostu irracjonalny, to nie zmienia to faktu, że i w jego obrębie odnajdziemy właściwą mu strukturę logiczną. Członkowie najmniej ucywilizowanych społeczności, podobnie jak my, nie mogą żyć w świecie bez podjęcia próby jego zrozumienia, ujęcia w określone formy. Oczywiście nie stosują w tym celu praw dialektyki, ale nie można im odmówić zdolności korzystania z charakteryzujących dialektykę zasad syntezy czy analizy. Reasumujacc: „To nie treść jest tym, o co chodzi, lecz sposób klasyfikacji; ta zaś forma jest całkowicie logiczna. Tym, co tu odkrywamy,

19 Esej, s. 174.

20 E. Cassirer, Die Philosophie..., cyt. za H. Buczyńska, Cassirer, wyd. cyt., s. 90-91.

21 Zob. Mit, s. 24-25. 
nie jest bynajmniej brak jakiegokolwiek porządku; jest to raczej pewna hipertrofia, nadmiar i bujny rozkwit "instynktu klasyfikowania"' 22.

Jak już wspomnieliśmy, próba podjęcia analizy mitu wyłącznie od strony intelektualnej musi zakończyć się niepowodzeniem, bo co prawda mówimy tu o formie myślenia, jednakże jest to forma, w którą immanentnie wpisany jest czynnik emocjonalny. Jednocześnie mit nie jest samą emocją, lecz emocją przetworzoną. Człowiek w ujęciu Cassirera tym bowiem różni się od zwierzęcia, że pomiędzy nim a światem, pomiędzy „systemem receptorów a systemem efektorów" 23 odnaleźć można trzecie ogniwo - system symboliczny. Stąd człowiek, będący animal symbolicum żyje niejako w nowym wymiarze rzeczywistości, w którym bodziec zewnętrzny nie spotyka się z natychmiastową i bezpośrednią reakcją (tak, jak ma to miejsce w świecie organicznym), lecz z reakcją opóźnioną o skomplikowany proces myślowy. „Człowiek nie żyje już w świecie jedynie fizycznym, żyje także w świecie symbolicznym. Częściami składowymi tego świata są: jezzyk, mit, sztuka i religia. Są to różnorakie nici, z których utkana jest owa symboliczna sieć, splątana sieć ludzkiego doświadczenia" ${ }^{24}$. Tyle że w przypadku mitu symbol i to, co on symbolizuje, emocja i myśl, są ze sobą tożsame, człowiek pierwotny wyraża swe emocje i uczucia w formie bezpośredniej i konkretnej, a nie w sposób abstrakcyjny. Mit nie jest zatem czystą emocją, lecz „emocją obróconą w obraz" 25 , tak samo jak wyrażenie uczucia jest czymś innym niż samo uczucie. Służy to temu, by to, co niejasne, nieokreślone, niewyraźne, nabrało konkretnego, określonego kształtu. Ekspresja symboliczna spełnia w ten sposób zadanie obiektywizacji. To znów zbliża mit do języka, który odpowiada za obiektywizację postrzeżeń zmysłowych, podczas gdy pierwszy obiektywizuje uczucia. Charakterystyczną właściwością odróżniającą ekspresję symboliczną od fizjologicznej jest również intensyfikacja wyrażanych emocji. Te skierowane są na zewnątrz - tak jak w przypadku reakcji fizycznych - ale miast się rozpraszać, ulegają skoncentrowaniu. „W języku, w micie, w sztuce, w religii nasze uczucia nie przemieniają się po prostu w zwykłe działania, czyny, zmieniają się w 'dzieła'. Te dzieła nie marnieją. Są trwałe i nieprzemijające. Reakcja fizyczna może jedynie przynieść nam krótką i chwilową ulgę [...]" 26. Mit jako pierwszy uczy człowieka pierwotnego sztuki wyrazu, co wiąże się z umiejętnością organizowania swych nadziei, pragnień i lęków. Formy, jakie przybierał, mogą człowiekowi cywilizowanemu wydać się dziwaczne czy nierzadko śmieszne, ale to mit na

22 Tamże, s. 26.

23 To rozróżnienie Cassirer czerpie z prac J. v. Uexkülla, zob. np. Esej, s. 79.

24 Tamże, s. 80.

25 Mit, s. 57.

26 Tamże, s. 61. 
długo przed filozofią dawał rozwiązanie problemu śmierci, czyniąc go zrozumiałym i znośnym.

Mircea Eliade twierdził, że zasadnicza funkcja mitu polega na „ustalaniu wzorców wszelkich obrzędów i wszelkich znaczących czynności ludzkich" 27. Cassirer zauważył tymczasem, że istnieją plemiona pierwotne, które nie posiadając żadnej rozwiniętej mitologii nadal zdradzają wszelkie cechy życia przenikniętego przez mit. Cechy te przejawiają się nie w konkretnych ideach, ale w działaniu. Płynie stąd wniosek, że dla zrozumienia mitu, musimy najpierw poznać obrzęd. Rytuały są manifestacjami życia psychicznego człowieka, jego lęków, radości, najgłębszych pragnień. Obrzęd, będąc wyrazem emocji, nie pyta o przyczynę zjawisk i niczego nie wyjaśnia - taką rolę spełnia właśnie mit.

Rytuały są w istocie motorycznymi manifestacjami życia psychicznego. Odkrywają one pewne zasadnicze tendencje, pożądania, potrzeby, pragnienia, a nie tylko „przedstawienia” lub „pojęcia”. I te tendencje dają się przełożyć na [...] rytmiczne i uroczyste ruchy lub dzikie tańce. [...] Mit jest w pierwotnym życiu religijnym elementem epicznym, rytuał stanowi element dramatyczny. Musimy zacząć od studiowania rytuału, aby zrozumieć mit. Same w sobie mityczne opowieści o bogach czy herosach nie są w stanie odsłonić nam tajemnicy religii, ponieważ są jedynie interpretacjami rytuałów ${ }^{28}$.

Trudno wskazać pierwszeństwo mitu bądź obrzędu, ponieważ oba są ze sobą ściśle związane, wpływając i podtrzymując się wzajemnie. Możemy za to wskazać, czemu służą rytuały. Czynią one zadość pragnieniu jednostek stopienia się z życiem przyrody i wspólnoty. Jest to zatem więź uczuciowa, a nie przyczynowa. Nie są ważne „[...] empiryczne związki pomiędzy przyczynami a skutkami, ale intensywność i głębia odczuwania związków między ludźmi" 29. Dotyczy to także interpretacji pokrewieństwa. Związek krwi nie uzyskuje wyjaśnienia fizjologicznego, lecz mityczne. Gdy nie zna się zasad prokreacji, można ją uznać za formę wędrówki dusz.

Cassirer niejednokrotnie podkreśla, że nie można traktować mitu jako pewnego rodzaju irracjonalnego czy też „prelogicznego” sposobu myślenia, właściwego ludziom pierwotnym, który w zasadzie należy już do przeszłości. Sedno sprawy polega na zrozumieniu, że nie mamy tu do czynienia z, jak to ujął jeden z badaczy Cassirerowskiej koncepcji mitu - Ashley Montagu, ze zwykłym odzwierciedleniem czy mirażem rzeczywistości, lecz z pewnym charakterystycznym do

27 M. Eliade, Sacrum. Mit. Historia, przeł. A. Tatarkiewicz, Warszawa 1974, s. 109.

28 Mit, s. 40.

29 Tamże, s. 52. 
niej podejściem ${ }^{30}$. Typowa dla mitu struktura syntetyzowania wrażeń i pewnego rodzaju organizowania świata naszych doświadczeń jest wciąż obecna i zajmuje miejsce u boku struktur właściwych nauce, sztuce czy religii ${ }^{31}$. Jako taka nigdy nie przeminęła i pewnie nigdy nie przeminie. Co gorsza, zawsze służy „pomocą” w chwilach kryzysu, w chwilach, gdy zawodzą racjonalne metody interpretowania rzeczywistości. Wówczas nawet człowiek XX i XXI wieku staje na tej samej pozycji, co człowiek pierwotny, który dla opanowania niezrozumiałych dla siebie zjawisk ucieka się do pomocy magii. Ubiegłe stulecie w tragiczny sposób dowiodło, że szczególnie podatną na tego rodzaju praktyki jest sfera polityki. Nie ma oczywiście gwarancji, że poznanie mechanizmów działania mitów politycznych może zapobiec powtórce z historii, ale z pewnością pomoże w zrozumieniu przeciwnika, jak to ujął Cassirer w jednym z najczęściej cytowanych fragmentów Mitu państwa ${ }^{32}$. Stąd należy mieć na uwadze, że w sytuacjach krytycznych człowiek każdej epoki ucieka się do pomocy desperackich środków, o czym doskonale wiedzą także współcześni „magowie” polityki próbujący uwieść lud wizją cudownych rozwiązań.

Dojście do władzy narodowych socjalistów w Niemczech zakończyło okres wiary w pełni racjonalny charakter cywilizowanego społeczeństwa. Wiara ta podparta była także wysiłkiem filozofów wielu epok, którzy usilnie starali się wyrugować myśl mityczną z życia społecznego i politycznego. Począwszy od Platona usuwającego poetów jako piewców mitu ze swego idealnego państwa, a skończywszy na Comtcie wieszczącym osiągnięcie przez rozum stadium „pozytywnego”, czy też naukowego, po wcześniejszym przezwyciężeniu stadium mitycznego i metafizycznego, najtęższe umysły starego kontynentu torowały drogę tryumfowi rozumu nad mrokami mitu ${ }^{33}$. Tymczasem okazało się, że:

30 Por.: M. F. A. Montagu, Cassirer on Mythological Thinking, [w:] The Philosophy of Ernst Cassirer, ed. by P.A. Schilpp, La Salle 1973, s. 373.

31 Język jest do tego stopnia przeniknięty przez mit, że, jak przekonuje Cassirer, „mówimy” mitem, nie zdając sobie z tego w ogóle sprawy. Ludzka mowa jest pełna metafor, których źródeł szukać należy w tej samej skłonności do personifikowania zdarzeń i rzeczy, która leży u podstaw myślenia mitycznego. Usunięcie pierwiastka mitycznego z języka, czy z kultury w ogóle, byłoby równoznaczne z ich zubożeniem (zob. E. Cassirer, The Technique..., [w:] Symbol..., wyd. cyt., s. 245).

32 Zob. Mit, s. 328.

33 Istotnym wyłomem w filozoficznym dziele usuwania myślenia mitycznego z życia społecznego i politycznego był niemiecki romantyzm, który według Cassirera utorował drogę dla późniejszego rozwoju nacjonalistycznego i faszystowskiego mitu państwa. Wówczas to poeci i filozofowie zatoczyli niejako krąg od Platona, wykluczając ze swego „państwa” polityków”. Zob. E. Cassirer, The Myth of the State, [w:] tenże, Gesammelte Werke. Hamburger Ausgabe, t. 24 - Aufsätze und kleine Schriften 1941-1946, s. 262. Jednocześnie, zaznacza Cassirer, romantyczne rozumienie mitu znacząco różni się od współczesnego. Dla romantyków była to „spontaniczna gra wyobraźni", gdy tymczasem w XX w. tworzy się mity według uznania oraz dla politycznych celów (zob. E. Cassirer, Judaism and the Modern Political Myths, [w:] Symbol..., wyd. cyt., s. 235. W niniejszej pracy odwołujemy się do dwóch tekstów noszących ten sam tytuł: Judaism and the Modern Political Myths. Cytowany powyżej, pochodzi z opracowanego przez Verene'a 
Mit [...] nie został naprawdę pokonany i opanowany. Trwa, stale obecny, kryjąc się $\mathrm{w}$ mrokach, czekając swojej godziny i odpowiedniej okazji, przyczajony w cieniu. Ta godzina nadchodzi, gdy tylko inne siły, krępujące życie człowieka w społeczeństwie, tracą z tej czy innej przyczyny swą siłę i nie potrafią już dłużej walczyć z demonicznymi siłami mitycznymi ${ }^{34}$.

To, co miało być trwałe i przewidywalne, okazało się być niestabilne i kruche. Stało się tak, ponieważ cywilizacja współczesna:

[... nie jest zbudowana na piasku; jest zbudowana na glebie wulkanicznej. Jej pochodzenie i podstawy nie są racjonalne, lecz mityczne. Myśl racjonalna jest tylko górnym pokładem dużo starszej warstwy geologicznej sięgającej odległych głębin. Musimy być zawsze przygotowani na poważne wstrząsy, które mogą naruszyć podstawy naszej kultury i porządku społecznego ${ }^{35}$.

Oczywiście człowiek współczesny nie zadowoli się już rozwiązaniami wyraźnie nierozumnymi. Pragnie on jakiejś „racji” dla swojej wiary, teoria usprawiedliwiająca jego przekonania nie może być prymitywna. Przed współczesnymi magami stoi więc zadanie tworzenia mitu na miarę czasów. Składanie obietnic, wskazywanie winnych i przekonywanie, że zna się lekarstwo na najdokuczliwsze bolączki to jedno, ale trzeba też ubrać to w przekonującą formę, która będzie wabiła swojac „racjonalnością” 36. Wszak nagonka na Żydów nie była motywowana wprost, czystą nienawiścią, trzeba jeszcze było tę nienawiść ukryć pod płaszczem „racjonalnych” i „szlachetnych” motywacji. Wiek XX, nazywany dumnie „wiekiem techniki”, stworzył też technikę mitu politycznego, która okazała się być przełomowa dla zwycięstwa nazistów.

Mit przestał być wolną i spontaniczną grą wyobraźni. Ujęto go w zasady i zorganizowano, przystosowano do potrzeb polityków i użyto do konkretnych politycznych celów. To, co wcześniej jawiło się jako nieposkromiony, nieświadomy proces, poddano surowej dyscyplinie, skontrolowano i przysposobiono do posłuszeństwa i porządku. Mity zostały powołane do życia na rozkaz przywódców politycznych. Stały się sztuczną miksturą wyrabianą w wielkim laboratorium polityki, tworzoną wedle uznania ${ }^{37}$.

\footnotetext{
zbioru rękopiśmienniczej spuścizny Cassirera i stanowił najprawdopodobniej wstępny szkic do artykułu, który ukazał się później w czasopiśmie „Contemporary Jewish Record” 7 [1944]. Celem uniknięcia konfuzji, w przypadku odwoływania się do tekstu zawartego w zbiorze Verene'a, używać będziemy zwrotu: Judaism [Ver]).

34 Tamże, s. 310

35 E. Cassirer, The Myth of the State, wyd. cyt., s. 264.

36 Fakt, że mit jest w pewnym sensie całkowicie „zracjonalizowany” stanowi dla Cassirera jeden z największych paradoksów w historii. Jak pisze: „Mit pozostaje irracjonalny co do treści, ale jego cele są jasne i świadome". (patrz: Judaism [Ver], s. 236).

37 Idem, Judaism and the Modern Political Myths, [w:] idem, Gesammelte Werke. Hamburger Ausgabe, t. 24 - Aufsätze und kleine Schriften 1941-1946, s. 198.
} 
„Technika” mitu wychodzi od jego, nazwijmy to, społecznego charakteru. Cassirer powołując się na badania Edmonda Doutté stwierdza, że mit jest „uosobionym pragnieniem zbiorowym" 38 , a bogowie i demony to nic innego jak personifikacje takich pragnień. Przy okazji uzyskujemy wgląd w przyczyny narodzin nowoczesnej dyktatury czy idei wodzostwa. „Potrzeba wodzostwa pojawia sie dopiero wtedy, kiedy zbiorowe pragnienie osiągnęło przytłaczającą siłę i kiedy, z kolei, zawiodły wszystkie nadzieje na spełnienie tego pragnienia w zwykły i normalny sposób" 39 . W czasach kryzysu takie pragnienie przybiera oczywiście na sile, by wreszcie znaleźć ucieleśnienie w konkretnym przywódcy. Ten dysponuje autorytetem i niemal mistyczną mocą, która unieważnia dotychczasowe więzi społeczne, stając ponad prawem i konstytucją. W społecznościach pierwotnych spotykamy czarownika, który mocą zaklęć potrafi pokonać wszelkie zło i każdego wroga. Współczesny człowiek raczej nie podziela wiary w moc czarownika, za to, jak przekonuje Cassirer, „[...] nie zarzucił bynajmniej wiary w 'magię społeczną'. Jeśli zbiorowe życzenie daje się odczuć z całą swoją siłą i z całą intensywnością, to łatwo przekonać ludzi, że potrzebny jest tylko właściwy człowiek, aby to życzenie spełnić" ${ }^{40}$. To zadanie wypełniają specjaliści od mitu kreujący przywódcę łączącego w sobie cechy homo magus i homo faber. Taki przywódca jest:

[...] kapłanem nowej, całkowicie irracjonalnej i tajemniczej religii. Kiedy jednak musi bronić tej religii i propagować ją, postępuje bardzo metodycznie. Nic nie zostaje pozostawione przypadkowi; każdy krok jest starannie przygotowany i z góry przemyślany. I to dziwne połączenie jest jedną z najbardziej uderzających cech naszych politycznych mitów ${ }^{41}$.

Co więcej, nowy lider ma także dar przepowiadania przyszłości i objawiania woli bogów, zyskując dodatkowo miano homo divinans ${ }^{42}$. Również $\mathrm{w}$ tym przypadku mamy do czynienia z powrotem człowieka cywilizowanego do, wydawałoby się, archaicznych zwyczajów. Jedyna różnica polega na tym, że współczesne proroctwa ubrane są w szatę metod naukowych czy filozoficznych ${ }^{43}$. W ten oto sposób, raczej siłą wyobraźni niż siłą fizyczną, mit polityczny zdobywa moc poruszenia

\footnotetext{
38 Zob. Mit, s. 311.

39 Tamże.

40 Tamże, s. 312.

41 Tamże, s. 313

42 Zob. tamże, s. 320

43 Warto w tym kontekście zwrócić uwagę na nowe rozumienie pojęcia prawdy. Pytanie o prawdziwość nowego mitu politycznego jest równie bezzasadne jak pytanie o prawdziwość karabinu maszynowego czy samolotu. I tu, i tu mamy do czynienia z bronią, a jedynym wyznacznikiem jej wartości jest skuteczność. Jeśli więc mit dowiedzie swojej skuteczności, nie musi się troszczyć o żadną inną formę legitymizacji (Judaism [Ver], s. 237).
} 
mas ludzkich. „Istotnym elementem w nowej sztuce rządzenia - pisze Cassirer stało się prorokowanie. Składane są najbardziej nieprawdopodobne lub całkiem niemożliwe do spełnienia obietnice i wciąż od nowa przepowiadane jest nadejście millenium" 44.

Nowoczesne mity polityczne cechuje też charakterystyczne podejście do języka. W historii cywilizacji słowo pełniło najczęściej dwie funkcje - semantyczną i magiczną. Ta pierwsza obecna jest zawsze, występuje nawet w najmniej rozwiniętych językach. Druga z kolei dominuje w społecznościach pierwotnych. Słowo magiczne służy przede wszystkim osiągnięciu pożądanych celów i wywarciu wpływu na bieg przyrody. Tylko wybrane jednostki, magicy lub czarownicy, mogą posiąść władzę nad słowem magicznym, którego sile nic nie jest w stanie się przeciwstawić. Cassirer zauważa, że obecnie mamy do czynienia z powrotem do tego rodzaju praktyk, a słowo semantyczne stopniowo ustępuje pola magicznemu. Przyznaje nawet, że nie rozumie już języka niemieckiego po tym, jak nowy mit zmienił znaczenie znanych mu słów lub wprowadził na ich miejsce nowe. Kiedyś używano słów w znaczeniu semantycznym, logicznym, opisowym, teraz używa się ich jako słów magicznych, które mają wywołać odpowiednie emocje. „Nasze zwykłe słowa - pisze - są naładowane znaczeniami, lecz owe na nowo użyte słowa są już nasycone uczuciami i gwałtownymi namiętnościami" ${ }^{45}$. Nie liczy się treść tych słów, ani ich obiektywne znaczenie, ale aura emocjonalna, która im towarzyszy ${ }^{46}$. Jeśli mielibyśmy się pokusić o jakąś współczesną ilustrację, można by wspomnieć o użyciu słowa „Żyd” jako popularnej wśród kibiców piłkarskich obelgi skierowanej w stronę fanów i graczy rywali. Jego znaczenie semantyczne jest oczywiste, podczas gdy w tym specyficznym, magicznym znaczeniu, słowo to nasycone jest całą gamą negatywnych emocji - pogardą, nienawiścią, gniewem, lekceważeniem, wściekłością. Naturalnie rzecz biorąc, wykrzyczenie tego „zaklęcia” spotyka się zazwyczaj z równie agresywną reakcją drugiej strony, czyniąc zadość twierdzeniu Cassirera, że symboliczne wyrażenie emocji doprowadza do ich intensyfikacji.

Magicznym słowom do osiągnięcia pełni mocy potrzebny jest jeszcze odpowiedni rytuał. Ciągłe powtarzanie tych samych słów, gestów czy znaków prowadzi

\footnotetext{
44 Tamże.

45 Tamże, s. 314.

46 Powołując się na Heinza Paechtera i jego Nazi-Deutsch. A Glossary of Contemporary German Usage, Cassirer porównuje dwa terminy: Siegfriede i Siegerfriede. Pierwszy miałby oznaczać pokój będący następstwem zwycięstwa Niemiec, podczas gdy drugi pokój w następstwie zwycięstwa ich wrogów. Różnica uwidacznia się w użyciu liczby mnogiej w przypadku Siegerfriede. Liczba pojedyncza może bowiem odnosić się wyłącznie do Niemców, którzy w myśl nazistowskiej propagandy stanowią prawdziwy corpus mysticum, homogeniczną całość, złączoną mistycznymi więzami. Alianci dla odmiany są przypadkową mieszaniną ras, kultur i idei. W ten oto sposób, za pośrednictwem jednej sylaby, przemyca się całą gamę emocji: nienawiści, gniewu, pychy czy pogardy (patrz: E. Cassirer, The Technique..., [w:] Symbol..., wyd. cyt., s. 255).
} 
w ostateczności do uśpienia naszej zdolności do krytycznego zdystansowania się i utraty poczucia własnej osobowości. Ponadto, gdy w państwie totalitarnym rytuał obejmuje każdą sferę życia, nie sposób nawet uciec w sferę osobistej wolności. Bodaj najpoważniejszą konsekwencją władzy rytuału jest jednak zanik odpowiedzialności indywidualnej. Całkowite zrytualizowanie życia prowadzi nas z powrotem do modelu życia społecznego typowego dla wspólnot archaicznych.

Tym, czego brakuje w życiu społeczności pierwotnych, lub przynajmniej jest całkowicie nierozwinięte, co znajduje się, powiedzmy w stanie embrionalnym, jest idea i wzorzec jednostkowej odpowiedzialności moralnej. Liczą się następstwa czynu, a nie stojące za nim motywy. Następstwa są także całkowicie niezależne od intencji winowajcy. Najpoważniejsze zagrożenie zawsze bierze się z pogwałcenia jakiegoś tabu. Takie zagrożenie jest tożsame z czysto fizycznym zakażeniem, które przenosi się na innych bez żadnych ograniczeń, tak samo jak wszelka fizyczna 'nieczystość' albo choroba. W całym tym systemie nie ma nawet cienia osobistej odpowiedzialności. 'Naznaczonym' nie jest wyłącznie ten, kto narusza tabu lub dopuszcza się zbrodni. To samo piętno nosi jego rodzina, przyjaciele i plemię ${ }^{47}$.

Narodowy socjalizm będący dla Cassirera modelową egzemplifikacją nowoczesnego mitu politycznego konsekwentnie zaprzeczał idei osobistej odpowiedzialności, utrzymując, że jeśli istnieje jakikolwiek podmiot „moralny”, to odpowiedzialność za jego czyny spływa na jego naród czy rasę. Krótko mówiąc, wartość moralna takiego czynu uzależniona jest od tego, czy jest on dziełem przedstawiciela rasy panów czy podludzi.

W odróżnieniu od typowych dyktatur, mit nazistów nie tyle opierał się na represji, lecz na dokonanej wcześniej przemianie samego społeczeństwa, które odtąd znacznie łatwiej było poddać kontroli. Przede wszystkim jednak, ludzie przestali zadawać pytania, wykonywanie tych samych rytuałów sprawiło, że zaczęli oni tak samo myśleć, czuć i mówić. Klucza do wyjaśnienia genezy takiego poddania się wizji narodowych socjalistów Cassirer upatruje w analizie pojęcia „wolności”. Przypomina, za Kantem, że wolność etyczna nie jest faktem, lecz postulatem, że nie jest dana (gegeben), ale zadana (aufgeben) ${ }^{48}$. Nie tylko nie jest darem, który należy nam się z samego faktu bycia człowiekiem, ale jest tė̇ uciążliwym wyzwaniem. Oczywiście mowa tu o wolności etycznej rozumianej jako posłuszeństwo prawu moralnemu, którego wybór nie został podmiotowi narzucony z zewnątrz. W czasach poważnego kryzysu społecznego jednostka często traci wiarę we własne siły i taki wybór staje się dla niej szczególnie trudny, a ponieważ, jak twierdzi

47 E. Cassirer, Judaism..., s. 203.

48 Zob. Mit, s. 319. 
Cassirer, znacznie łatwiej jest być zależnym od innych niż decydować samemu, wolność zostaje uznana za brzemię. „W ekstremalnych warunkach człowiek próbuje zrzucić z siebie to brzemię. I tu wkraczają mity polityczne oraz państwo totalitarne" 49. Nowe partie polityczne czynią zadość temu dążeniu i za cenę wolności oswobadzają ludzi z ciężaru odpowiedzialności.

Analizy Cassirera w głównej mierze odnoszą się do narodowego socjalizmu, jako tej formy mitu politycznego, której narodziny i rozwój miał okazję oglądać z bliska, i która ostatecznie zmusiła go do emigracji. Nie jest to analiza historyczna, lecz próba zrozumienia podstaw mitu, by, jak już wspomniano, zrozumieć go i zobaczyć jak go pokonać. Narodowy socjalizm wydawał się tak niedorzeczny i tak sprzeczny z logiką nowoczesności, że elity polityczne i intelektualne nie były w stanie traktować go poważnie. Cassirer wyraźnie przestrzega przed popełnieniem tego samego błędu ${ }^{50}$.

W 2008 r. nastąpił krach na rynkach finansowych, który pociągnął za sobą światowy kryzys gospodarczy. Tam gdzie kryzys okazał się być szczególnie dotkliwy, natychmiast zyskały partie wprost odwołujące się do mitu narodowego (za przykład niech posłuży grecki Złoty Świt), co dowodzi, że rozważania Cassirera nie mają charakteru historycznego, czy czysto spekulacyjnego. Żydów w Europie prawie już nie ma, ale na ich miejsce pojawili się nowi „inni”. Dzisiaj głównie muzułmanie przez wielu uznawani są najpoważniejsze zagrożenie dla mitu „krwi i ziemi”. Oczywiście i w tym przypadku niechęć lub czasem zwykła nienawiść ubrana jest w szaty racjonalnej argumentacji. Tworząc obraz terrorystów, gwałcicieli czy po prostu prymitywów kamieniujących niewierne żony, nie pozostawia się "zdroworozsądkowemu” odbiorcy żadnego wyboru - tych ludzi należy wykluczyć z naszego świata. Z kolei tam, gdzie innych brakuje, sięga się do przeszłości lub szuka się innego we własnych szeregach. Tak jest np. w Polsce, gdzie co rusz tropi się ukrytą opcję żydowską, niemiecką czy rosyjską.

Wiele z opisywanych przez Cassirera technik mitu politycznego zostało też zaadaptowanych przez polityków wyraźnie dystansujących się od wszelkiego radykalizmu. Dziś niemal wszyscy przyjmują pozycję proroka i niemal wszyscy starają się poruszyć masy siłą wyobraźni. Wyborców mają uwodzić wielkie przedstawienia i wiece, przemawiające mocą quasi rytuału. Rozsławione przez Obamę hasło yes, we can, nosiło wyraźne cechy słowa magicznego. Specjaliści od współczesnych mitów politycznych doskonale wiedzą, że ludzie od lat lgnęli do rozwiązań magicznych i dziś także gotowi są to zrobić, byle tylko znaleźć klucz do ich serc i umysłów. Zamiast próbować trafiać w gusta, co jest często skazane

\footnotetext{
49 Tamże.

50 Zob. tamże, s. 328.
} 
na niepowodzenie, próbuje się najpierw te gusta urobić, by potem zaserwować ludziom to, czego „naprawdę potrzebują”. Przekonuje się np., że prawdziwy wróg to komunizm czy konserwatyzm i należy wybrać tego konkretnego kandydata, który jest ucieleśnieniem antykomunisty, bądź, odpowiednio, liberała. Struktura w obu przypadkach jest jednak ta sama - zło jest rozpoznane, należy się z nim niezwłocznie rozprawić i to właśnie my znamy na nie lekarstwo. Wielu to uwodzi, ale wielu też, być może nawet większość, męczy i każe stronić od polityki w ogóle. W obu przypadkach cierpi demokracja, która nie znosi ani radykalizmu, ani bierności.

Na szczęście Cassirer nie pozostawia nas bez oręża do walki z mitem. Samo jego poznanie to już wiele, bo nie można pokonać przeciwnika nie znając jego siły. Zwycięstwo nauki nad magią było możliwe dzięki posłuszeństwu idei, którą Francis Bacon zawarł w maksymie: Natura non vincitur nisi parendo ( „Nie można przyrody zwyciężyć inaczej niż przez to, że się jej słucha") ${ }^{51}$. Podobnie musi być z naszym podejściem do mitu.

Jednak konkretną metodę walki z mitem politycznym odnajdujemy w artykule The Myth of the State 52 . Pomocą służyć ma nam Spinoza, który twierdził, że namiętność (a na tej jak wiemy zasadza się mit) można pokonać tylko poprzez przeciwstawienie jej jeszcze większej namiętności. Możemy tego dokonać przez oddanie się czynnym emocjom - dzielności i szlachetności ${ }^{53}$. Tylko dzięki nim możemy osiągnąć pełnię wolności filozoficznej i etycznej. Wolność ta nie tylko ma nas trzymać z dala od gwałtownych namiętności i żądz, ale także z dala od fałszywych idei i wszelkiego rodzaju uprzedzeń i zabobonów. Dzielność to odwaga bycia mądrym i życia w sposób niezależny, aktywny i racjonalny. Nie możemy jednak poprzestać na wyzwoleniu siebie samych:

Musimy swobodnie przekazywać innym dobro, które sami osiągnęliśmy. By móc to uczynić potrzeba nam emocji czynnej - szlachetności. Dzielność i szlachetność to jedyne sposoby zdobycia i zabezpieczenia wolności umysłu jednostki i całego społeczeństwa. Poprzez pierwszą udoskonalamy samych siebie, dzięki drugiej budujemy prawdziwie ludzki ład społeczny ${ }^{54}$.

\footnotetext{
51 F. Bacon, Novum organum, Warszawa 1955, s. 57.

52 Proponowana przez Cassirera walka ze współczesnymi mitami politycznymi zdaje się być dość mocno powiązana ze swoistą rehabilitacją filozofii. Jakkolwiek nie można posądzać „królowej nauk" o współudział w tworzeniu ideologii narodowych socjalistów, to, jak twierdzi autor Eseju o czlowieku, istnieje pośredni związek pomiędzy ogólnym kierunkiem idei, które znaleźć można u Spenglera czy Heideggera, a tymi, które towarzyszyły życiu politycznemu i społecznemu Niemiec okresu międzywojennego (zob.: E. Cassirer, Philosophy and Politics, [w:] Symbol..., wyd. cyt., s. 230).

53 Zob. B. Spinoza, Etyka, [w:] tenże, Traktaty, przeł. I. Halpern-Myslicki, Kęty 2003, s. 576. Cassirer używa tu zwrotów fortitude (dzielność) i generosity (szlachetność), podczas gdy faktycznie u Spinozy szlachetność przynależy do dzielności, podobnie jak wytrwałość.

54 E. Cassirer, The Myth..., s. 265.
} 
Należy zatem mieć na uwadze, że współcześni radykałowie chętnie szermują podobną argumentacją. W takim wypadku warto posłużyć się metodą właściwą Cassirerowi - słuchać uważnie i wyciągać ostateczne konsekwencje z głoszonych teorii. Uzyskamy w ten sposób jaśniejszy obraz tego, co mogłoby się stać w przypadku tryumfu danej idei i pewnie pozbędziemy się sporej części wątpliwości. To znów rola dzielności, rolą szlachetności jest za to dzielenie się wnioskami ze światem.

\section{Ernst Cassirer's Conception of Political Myth and its Validity}

\section{Summary}

Cassirer's conception of the modern political myth needs to be treated as one of the elements of his philosophy of culture. To apprehend the conception without its systemic background would be against the "spirit" of this specific type of philosophy which is characterised by focus on coherent unity. It is true, however, that Cassirer only devoted his last writings to this topic, in the period when he lived a life of an exiled Jewish intellectual. Myth as a specific form of thought has never lost its power and it easily takes control over people's minds and emotions in the times of crisis. Modern politicians are well aware of this fact. They organize myth and adjust it to their political needs and use it for their concrete political ends. The only solution is to understand the nature of the new myth and to fight it with fortitude and generosity.

Key words: cultural sciences, fascism, judaism, language, myth, Neo-Kantian Marburg School politics, symbolic forms

Słowa kluczowe: nauki o kulturze, faszyzm, judaizm, język, mit, teoria polityki szkoły marburskiej

\section{Bibliografia}

Bacon, F., Novum organum, przeł. J. Wikarjak; przekł. przejrzał, wstępem i przypisami opatrzył K. Ajdukiewicz, PWN, Warszawa 1955.

Buczyńska, H., Cassirer, Wiedza Powszechna, Warszawa 1963.

Cassirer, E., Esej o człowieku, przeł. A. Staniewska, Czytelnik, Warszawa 1977.

Cassirer, E., Gesammelte Werke. Hamburger Ausgabe, t. 12 - Die Philosophie der symbolischen Formen. Zweiter Teil: Das mythische Denken. Meiner, Hamburg 2002.

Cassirer, E., Gesammelte Werke. Hamburger Ausgabe, t. 24 - Aufsätze und kleine Schriften 1941-1946, Meiner, Hamburg 2007.

Cassirer, E., Language and Myth, Dover Publications Inc., New York, 1953.

Cassirer, E., Logika nauk o kulturze. Pięć studiów, P. Parszutowicz, Wydawnictwo Marek Derewiecki, Kęty 2011. 
Cassirer, E., Mit państwa, przeł. A. Staniewska, Wydawnictwo Instytutu Filozofii i Socjologii PAN, Warszawa 2006.

Cassirer, E., Substancja i funkcja. Badania nad podstawowymi problemami krytyki poznania, przeł. P. Parszutowicz, Wydawnictwo Marek Derewiecki, Kęty 2008.

Cassirer E., Symbol, Myth and Culture. Essays and Lectures of Ernst Cassirer 1935-1945, red. D. Ph. Verene, Yale University Press, New Haven and London, 1979.

Eliade, M., Sacrum. Mit. Historia, Państwowy Instytut Wydawniczy, Warszawa 1974.

Hanuszkiewicz, W., Filozofia Hermanna Cohena w perspektywie sporu o jedność metody transcendentalnej, Wydawnictwo Instytutu Filozofii i Socjologii PAN, Warszawa 2011.

Kant, I., Krytyka czystego rozumu, t. 1, przeł. R. Ingarden, PWN, Warszawa 1957.

Kant, I., Krytyka czystego rozumu, t. 2, przeł. R. Ingarden, PWN, Warszawa 1986.

Lisak, A., Filozofia transcendentalna między Heglem a Heideggerem. Od teorii poznania do ontologii, Wydawnictwo Politechniki Gdańskiej, Gdańsk 2012.

Montagu, M. F. A., Cassirer on Mythological Thinking, [w:] The Philosophy of Ernst Cassirer, red. P. A. Schilpp, Open Court Publishing Company, La Salle, Illinois, 1973.

Noras, A., Historia neokantyzmu, Wydawnictwo Uniwersytetu Śląskiego, Katowice 2012.

Noras, A., Kant a neokantyzm badeński i marburski, Wydawnictwo Uniwersytetu Śląskiego, Katowice 2000.

Parszutowicz, P., Fenomenologia form symbolicznych. Podstawowe pojęcia i inspiracje „późnej” filozofii Ernsta Cassirera, Warszawa 2013.

Parszutowicz, P., The Idea of Transcendental Philosophy in Perspective of the Kantian Opposition of Aggregate and System, [w:] „Archiwum Historii Filozofii i Myśli Społecznej" 58, 2013.

Spinoza, B., Traktaty, przeł. I. Halpern-Myślicki, Wydawnictwo Marek Derewiecki, Kęty 2003.

Tatarkiewicz, W., Szkoła marburska i jej idealizm (W setna rocznice marburskiej dysertacji Profesora Wtadystawa Tatarkiewicza), red. P. Parszutowicz, Wydawnictwo Marek Derewiecki, Kęty 2010.

Tomasz Sikora - absolwent filozofii na UMK w Toruniu, dziennikarz, podróżnik; e-mail: siedzi@wp.pl 